\title{
各種建物における電源及び給水設備の容量と非常時の 供給計画に関する研究

\author{
STUDY OF THE CAPACITY OF ELECTRICITY RESOURCE \\ AND WATER SUPPLY EQUIPMENT AND THE PLANNING \\ OF WATER SUPPLY IN AN EMERGENCY
}

\author{
洪 元 和*, 高橋 信 之**, 尾島俊 雄*** \\ Wonhwa HONG, Nobuyuki TAKAHASHI and Toshio OJIMA
}

\begin{abstract}
The main purpose of this research is the study of the building equipment facilities such as the supply of electricity and water in emergency in Tokyo.

1) There are many buildings with a self-generator for electricity supply and extremely few buildings with an own water supply equipment in time of suspension of electricity and water.

2) In normal time the air-conditioning operating rate is high but in time of an emergency the operating rate is low. The watersupply for the extinguish of fire and for sanitary is in an emergence about the same as in normal time.

3) The possession of building equipment and fuel storage, and activation for the rescue as well as the expected operation time in an emergency has been calculated.
\end{abstract}

\section{keywords : various building types, suspension of electricity and water, emergency building equipment, building maintenance-function 各用途建築物、停電時、断水時、非常用建築設備、建築機能維持}

1 .はじめに

\section{1 研究の背景}

1995年1月17日に起きた兵庫県南部地震は、大都市圈の直下型地震 てあり、巨大なエネルギーて、一瞬にして都市機能を麻疩させた。 しかしながら、本来災害時に中枢機能を果たすべき建築物や社会の 経済活動を支える上で特に重要な建築物は、災害時において外部か らエネルギー供給が遮断した場合てもその機能の重要な部分は維持 することが期待されている。

\section{2 研究の目的}

災害時を考慮した建築設備を計画する上て、ライフラインが停止

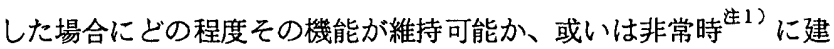
築設備の機能継続が要求されるのかが重要である。

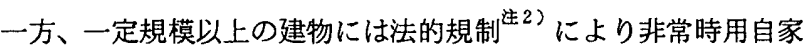
発電設備が設置されているが、それは燃料貯蔵量、機器の耐久性等 から考えて、最低限必要な電力すらわずか数十分から数時間しか供 給できないのが現状である。また、非常時用の水確保においても非 常電源確保之同様、法的規制 ${ }^{\text {住3) }}$ や地方自治体の地域防災計画 ${ }^{\text {注4 }}$ 等 で水槽の容量と供給量等を定めているが、各建物が保有している水 槽より非常時の給水形態や必要水量の供給が可能かどうかは明らか にされていない。本研究では、首都圈（東京都、神奈川県、千葉県、
埼玉県、以下首都圏と記す) の防災機関と一般建物に対し、建築設 備の中で特に重要と思われる電源設備と給水設備を取り上げた。各 設備容量之備蓄量、非常時設備機能の稼働可能時間と応急活動（以 後執務亡記す）、継続希望時間などの調查・分析を行い、今後の広 域災害における各用途別建物の設備計画の基礎資料をつくることを 目的としている。

\section{2. 調査概要}

\section{1 調査の対象}

著者らは既報で、首都圈の災害時救援活動を実施する上で重要な 建築物に対し、非常時活動マニュアルとエネルギ一消費や建築設備 と容量などに関して調查を実施し文献19て報告した。その内容は93 病院を対象亡したアンケート調查で、非常時における設備機能の重 要度と必要割合等を分析した。また、救援活動の基地となる117庁舎 に対してもアンケート調査を行い、非常時設備機能の重要度と必要 割合等を文献20に分析している。そこで本研究では更に、首都圈の 防災機関之、一般建物の中で都市中枢機能をもつ建物について、各 建物用途別に電源設備や給水設備の非常設備容量之緊急時における 設備機能の稼働可能時間と応急活動に対する希望継続時間などの調

\footnotetext{
* 慶北大学建築工学科 講師・博士 (工学)

** 早秒田大学理工学総合研究センター 助教授・工博

*** 早稲田大学建築学科 教授・工博
}

Lecturer, Kyungpook National Univ., Dr. Eng.

Assoc. Prof., Advanced Research Institute for Science and Engineering, Waseda Univ., Dr. Eng.

Prof., Waseda Univ., Dr. Eng. 
表1 アンケート配布及び回収状況

\begin{tabular}{|c|c|c|c|}
\hline 調查建物 & 配布数 & 有効回収 & \multirow{8}{*}{$\begin{array}{c}\text { 证*1 : 東京都地域防災 } \\
\text { 計画での庁舎、病 } \\
\text { 院、学校建物を除 } \\
\text { く防災指定公北機 } \\
\text { 開である。 }\end{array}$} \\
\hline 方舎 & 117 & 73 & \\
\hline 病院 & 51 & 40 & \\
\hline 教南 & 21 & 5 & \\
\hline 関防災指定 $* 1$ & 49 & 13 & \\
\hline 樿務 & 81 & 40 & \\
\hline 醕業 & 27 & 12 & \\
\hline 回収率 & & $52.9 x$ & \\
\hline
\end{tabular}

查・分析を実施したものである。ここで、調查対象の用途を整理す る亡、防災機関の(1)初動活動の本部亡なる庁舎（県庁、都庁、市役 所、区役所)、(2)応急医療を行う病院、(3)避難場所となる小中高大 学校 (以後教育建物之記す) 、(4)庁舎や病院亡避難場所を除く防災 指定公共機関（以後防災指定建物之記す）の 4 用途に、一般建物の 中で(5)通常時の都市中枢機能を持つ業務（主に丸の内、大手町地 区にある本社ビルで以後業務施設と記す）、(6)大勢の人が集まるテ パートや大型店舗（以後商業施設と記す）の合計 6 用途とした。ま た、各用途別調查件数は、宁舎 117 件、病院 51 件、教育施設 21 件、防 災指定49件、業務施設81件、商業施設27件となっている。

\section{2 調查の方法}

アンケート用紙の配布と回収は原則として郵送により、アンケー トの回答者としては各設備系統の貴任者に依頼した。ただし、回収 アンケートの不明簓所については電話によるヒアリングの追加調査 を行った。表 1 は配布・回収状況を示しており、アンケート全配布 数346件のうち183件から回収することができ、回収率は52.9\%であ った。有効回答サンプル数183件の建物の内訳は、庁舎が73件、病院 が40件、教育施設が 5 件、防災指定施設が 13 件、業務施設が 40 件、商 業施設が12件となっている。

\section{3 調查項目}

調查項目は、(1)建物概要として、㓍工年、階高、建物構造、建築 面積、延床面皘、架調面積、事務所面積、事務員数、来客者数等、 (2)設備概要として、電源設備、空調設備、(3)月別電力と上水消費量、 (4)非常時に対する調査項目として、各建築設備の機能の必要割合、 非常時防災活動と非常時執務可能時間、執務希望時間等である。

\section{4 調查時期及び記入テータ年度}

アンケート調査は1994年度に行い、電力と上水消費量の記録は199 3年度の1月から12月までのテータでる。本研究では183件の有効回 収サンプルに対し、統計処理上、無記入項目と平均値を中心に標準 偏差の 2 倍を越える範囲のデータについては不確定要素が多いため 除外し分析を行った。但し、分析母集団のサンプル数を表と図に表 記したか、有効サンプル数の明記がない図と表は有効回収サンプル 全体が母集団である。

\section{3. 分析結果}

\section{1 建物根要}

各用途別の建物概要を項目別に平均値、標準偏差、最大値、最小 值を表 2 に示す。建物竣工年をみる亡、教育の平均竣工年が古く、 業務全サンプルの望工年分布の幅が大きい。建物に常住する職員総 数では、教育（学生含む）建物に内在する人数が他の建物より多い。

\section{表2 調査建物の概要}

\begin{tabular}{|c|c|c|c|c|c|c|c|}
\hline & & 庁全 & 满院 & 教育 & 防災指定 & 歓扮 & 西業 \\
\hline \multirow[t]{4}{*}{ 欢工年 } & $A V G$ & 1972 & 1965 & 1952 & 1974 & 1971 & 1973 \\
\hline & SD & 12 & 17 & 14 & 14 & 15 & 11 \\
\hline & $Y_{A} X$ & 1992 & 1992 & 1965 & 1994 & 1993 & 1993. \\
\hline & Yi. & 1928 & 1926 & 1931 & 1951 & 1920 & 1962 \\
\hline \multirow[t]{4}{*}{ 地上陼数 } & $A V G$ & 7 & 9 & 7 & 12 & 15 & 8 \\
\hline & SD & 6 & 4 & 2 & 5 & 8 & $\bar{l}$ \\
\hline & $\overline{Y A X}$ & 48 & 19 & 9 & 23 & 43 & 9 \\
\hline & Yis & 2 & 4 & 5 & 3 & 3 & 7 \\
\hline \multirow[t]{4}{*}{ 延床面稓 } & AVG & 18884 & 41029 & 80119 & 51444 & 47113 & 35784 \\
\hline & SD & 24666 & 27292 & 64816 & 57076 & 36504 & 27205 \\
\hline & YAX & 195567 & 89721 & 199460 & 216500 & 135000 & 82893 \\
\hline & ViN & 2115 & 2313 & 3699 & 4473 & 3368 & 10777 \\
\hline \multirow{4}{*}{ 漛員総数 ［人] } & AVG & 945 & 733 & 7692 & 1833 & 1860 & 1202 \\
\hline & SD & 989 & 501 & 3931 & 1669 & 1199 & 1093 \\
\hline & $\operatorname{YAX}$ & 6800 & 1858 & 12065 & 6170 & 4025 & 3271 \\
\hline & MiN & 140 & 86 & 1675 & 205 & 40 & 120 \\
\hline \multirow[t]{4}{*}{ 1日来客者数 [人] } & AVG & 2336 & 1321 & $=$ & 1553 & 1355 & 43243 \\
\hline & $\overline{S D}$ & 3639 & 830 & - & 2605 & 2082 & 52461 \\
\hline & YAX & 23000 & 3940 & - & 8000 & 8000 & 173500 \\
\hline & vin & 110 & 244 & - & 30 & 30 & 3395 \\
\hline \multirow[t]{4}{*}{ 辟可病床数 [床] } & AYG & - & 592 & - & - & - & - \\
\hline & SD & - & 320 & - & - & - & - \\
\hline & XAX & - & 1176 & - & - & $-\ldots$ & - \\
\hline & YIN & - & 65 & - & - & $=$ & - \\
\hline \multirow[t]{4}{*}{ 入院患者数 [人] } & AVG & - & 493 & - & - & - & $=$ \\
\hline & SD & - & 292 & - & - & - & - \\
\hline & MAX & - & 1029 & - & - & - & - \\
\hline & MiN & - & 56 & - & - & - & - \\
\hline
\end{tabular}

また、学校の規模により学生数が違うため最小值と最大值の幅が大 きい。延床面積の中、庁舎の最大と最小値の幅が大きいのは、東京 都庁舎が含まれているからである。病院の平均許可病床数は592床て、 在院患者数は 493 人て、病床利用率は $83 \%$ でる。

\section{2 設備概要}

1) 電源設備

平均契約電力と自家発電設備や貯蔵燃料槽の容量を図 1 に示す。 契約電力亡自家発電容量を比べる亡、自家発電力が契約電力の約 5 割を占めている建物は庁舎や病院や業務建物て、防災指定建物は自 家発電力が契約電力の約 7 割を占めており、他の建物より自家発電 力の值が大きいが、教育建物は他の防災指定施設之は逆に自家発電 力の值が非常に小さかった。また、商業建物の自家発電力は契約電 力の約 2 割を占めていた。延床面積当たり自家発電機用の燃料夕ン クの容量は、值が大きい順に、防災指定 $\left(1.147 \mathrm{\ell} / \mathrm{m}^{2}\right)$ 、庁舎 $(0.2$ $\left.65 \ell / \mathrm{m}^{2}\right)$ 、病院 $\left(0.146 \ell / \mathrm{m}^{2}\right)$ 、業務 $\left(0.170 \ell / \mathrm{m}^{2}\right)$ 、商業 $(0.14$ $\left.0 \ell / \mathrm{m}^{2}\right)$ 、教育 $\left(0.012 \ell / \mathrm{m}^{2}\right)$ の順てある。以上のことから総合的 に見て、災害時の避難場所となる教育建物の自家発電力と燃料備蓄 量が他の施設より小さく、今後、非常時の建物機能維持に必要な電 力供給が短時間で供給不可能となる。自家発電機器用の燃料の種類 ては、各用途建物において重油が多く、次に軽油、軽油十重油、灯 油の順であった。図 2 に受電方式を示す。非常時に有効な多重方式

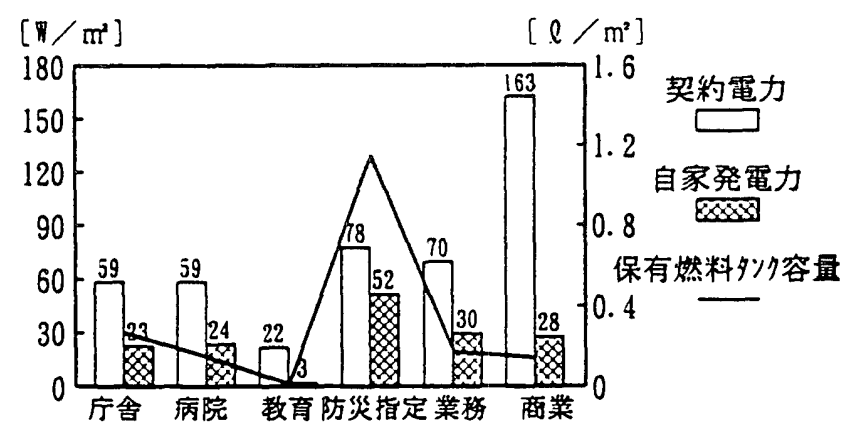

図1 平均契約電力と自家発電設備・貯葴燃料槽の容量 
の保有率をみると、防災機関である庁舎と教育建物の多重受電方式 の保有率が小さかった。

2 ) 給水設備

各用途建物別に飲料可能な水槽の容量を図 3 に示す。各水槽（受 水槽、高置水槽、消防用水槽、非常時用水槽）の容量は、庁舎が0. 0 $31 \mathrm{~m}^{2} / \mathrm{m}^{2}$ 、病院が $0.031 \mathrm{~m}^{3} / \mathrm{m}^{2}$ 、教育が $0.006 \mathrm{~m}^{3} / \mathrm{m}^{2}$ 、防災指定が 0.020 $\mathrm{m}^{\mathrm{i}} / \mathrm{m}^{2}$ 、業務が $0.015 \mathrm{~m}^{2} / \mathrm{m}^{2}$ 、商業が $0.024 \mathrm{~m}^{2} / \mathrm{m}^{2}$ でった。災害時の災 害対策本部となる庁舎建物で非常用の貯水槽の容量が大きい。また、 避難場所となる教育施設は震災時の避難民を考虑すると、現在の水 槽容量では不十分であると考えられる。

\section{3 電力・水消費量}

本研究ての電力と水消費変動の分析は建物の単位延へ床面積当た りに対して行い、各用途建物別の平均月別電力消費量を図 4 に、平 均月別上水消費量を図 5 に示す。各用途建物の平均年間電力消費量 の大きい順に、商業が $336 \mathrm{kWh} / \mathrm{m}^{2}$ •年、防災指定が $265 \mathrm{kWh} / \mathrm{m}^{2}$ •年、病 院が $200 \mathrm{kWh} / \mathrm{m}^{2}$ ・年、庁舎建物が $121 \mathrm{kWh} / \mathrm{m}^{2}$ ・年、業務が $194 \mathrm{kWh} / \mathrm{m}^{2}$ ・年、 教育が $49 \mathrm{kWh} / \mathrm{m}^{2}$ ・年であった。通常時の電力消費は商業が高く、教育 が非常に小さいか、非常時の活動を考えると、庁舎、防災指定、病 院、教育の電力は確実に確保できなければならない。

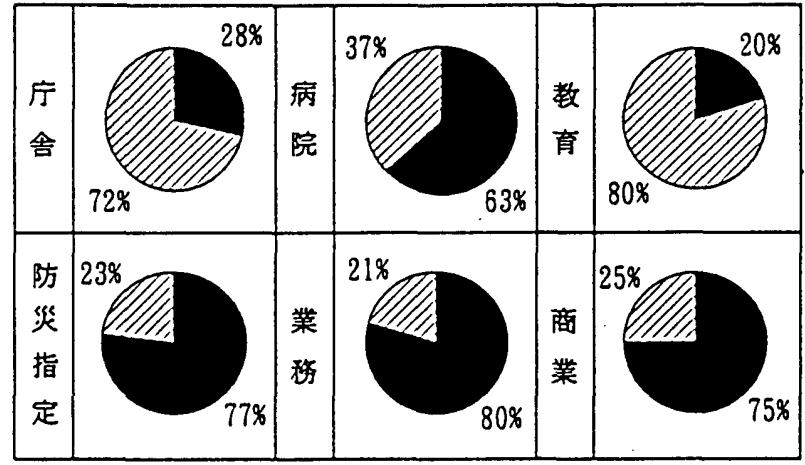

多回線方式 ए回線方式

図 2 受電方式

$\left[\mathrm{kWh} / \mathrm{m}^{2} \cdot\right.$ 月]

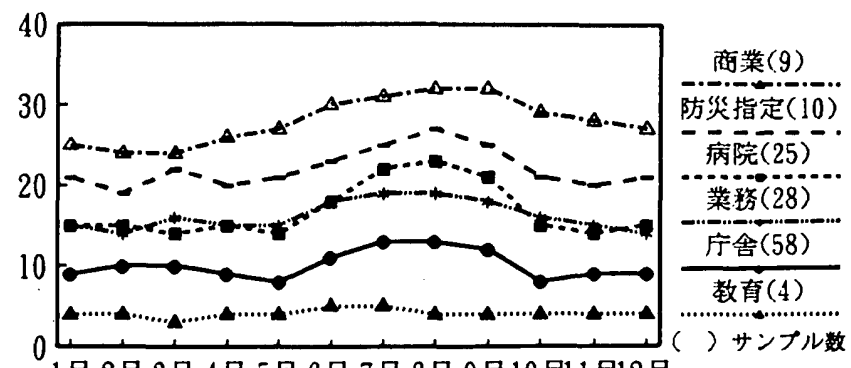

1月 2月 3月 4月 5月 6月 7月 8月 9月10月11月12月

図 4 電力消費量の平均月別変動

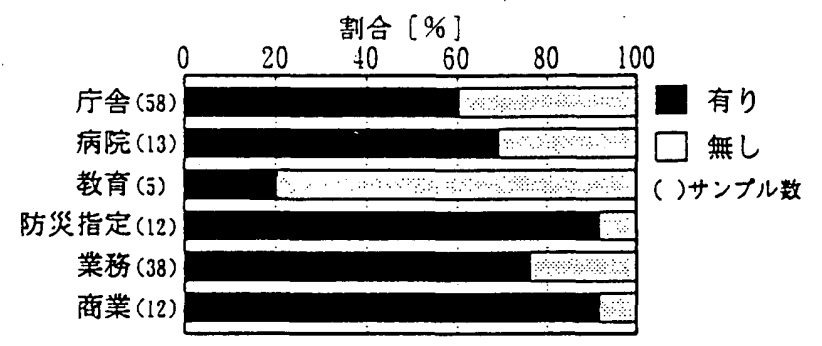

図 6 停電時の自家発電機による電力供給計画の有無
また、平均年間上水消費量は、病院が $4.67 \mathrm{~m}^{3} / \mathrm{m}^{2}$ •年、商業が 4.07 $\mathrm{m} / \mathrm{m}^{2}$ ・年、防災指定が $1.82 \mathrm{~m}^{3} / \mathrm{m}^{2}$ ・年、教育が $1.59 \mathrm{~m}^{3} / \mathrm{m}^{2}$ ・年、庁舎が 1 . $42 \mathrm{~m}^{\mathrm{T}} / \mathrm{m}^{2}$ ・年、業務が $1.00 \mathrm{~m}^{\mathrm{r}} / \mathrm{m}^{2}$ ・年であった。年間水消費量をみる亡、 病院之商業が他の建物より消費量が数倍多い。

\section{4. 非常時における電力・水供給計画及び容量分析}

\section{1 電力と水供給計画の有無}

停電時の自家発電機による電力供給計画の有無を図 6 に示す。停 電時に非常電源による系統別電力供給計画を持つ建物の割合が大き い順に、防災指定亡商業が $92 \%$ 、業務が $76 \%$ 、病院が $69 \%$ 、庁舎が 6 $2 \%$ 、教育が $20 \%$ でった。防災指定機関の庁舎、病院、教育建物の 非常時活動の重要性から見て、停電時の電力供給計画がない建物が 多く占めているのは問題である。

断水時における給水計画の有無ては、電力供給計画の保有率とは 逆に、保有率が非常に小さく（全体的に保有率が $30 \%$ 以下）、特に 教育建物の計画の保有率が0\%であった（図 7）。

\section{2 停電時における電力供給系統項目と負荷容量}

ここでは通常時における電源負荷容量と停電時に各建物が保有し ている自家発電機による電力供給負荷について分析を行った。

1）停電時における自家発電機による電力供給項目割合

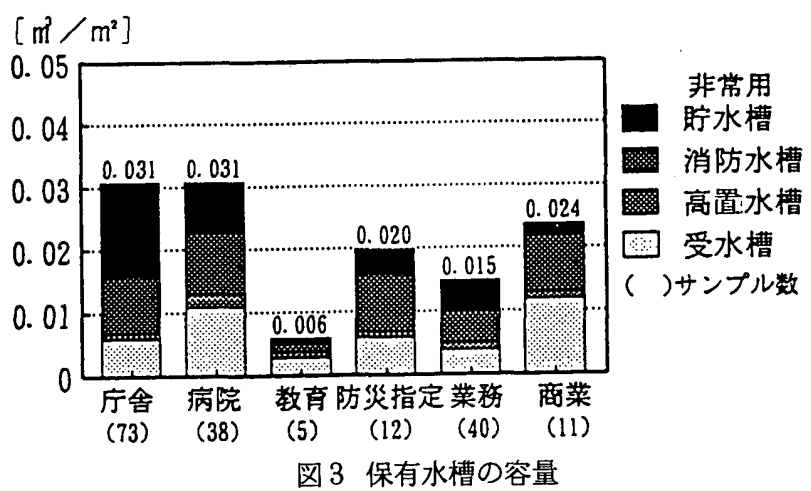

[ $\mathrm{m}^{3} / \mathrm{m}^{2}$ ・月 $]$
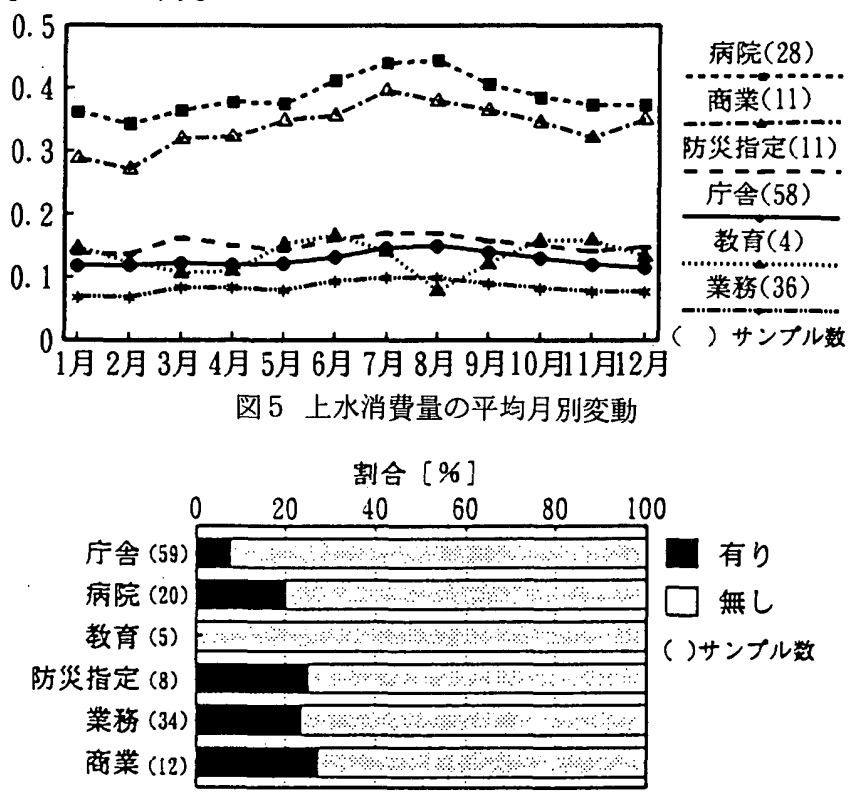

図 7 断水時の保有水による給水計画の有無 
各用途建物の停電時の自家発電機による電力供給項目件数割合を 図 8 示す。ここて、停電時の自家発電機による電力供給項目件数割 合は、図 6 に示した停電時の電力供給計画がある建物のみに対する 割合である。

\section{2 ）通常時と停電時に供給する電源負荷容量}

通常時の各系統別電力負荷では、圧倒的に動力負荷の空調負荷容 量が大きいが、停電時になると空調負荷は大きく減らすことが分か る。反面、消火や給排水衛生動力と防火災設備負荷などは停電時に その供給容量が通常時とほぼ同程度であった。特に、教育建物の停 電時電力確保が非常に小さいことが明らかになった（図 8)。

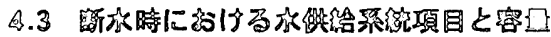

1）断水時における水詝蔵タンクによる水供給項目割合

各用途建物の断水時の水タンクによる水供給項目件数割合を図 9
示す。庁舎と業弱建物は、飲料用水の供給件数割合より便所用水の 供給件数割合が高かった。断水時に $80 \%$ 以上の建物が供給する水負 荷項目としては、庁舎が便所用だけで、病院が飲料用、便所用、时 房用、その他（主に手術室用之冷却水）で、防災指定が飲粼用、便 所用て、業務が便所用て、商業が飲料用である。教育は断水時の供 給計画を持っていなかった。

2 ）通常時と断水時に供給する水容量

各建物用途別に通常時 1 日全水消費量亡断水時 1 日全水供給量を 比較すると、病院の断水時における給水量は通常時水消費量の約 25 \%て、業務建物の通常時水消費量より多かった。また、防災指定の 断水時の給水量は病院と同じ程度であった。しかし、商業は断水時 に供給する総水量の計画は持っていたが、各用途項目別の給水計画 は持っていなかった。教育は断水時の給水計画そのものを持ってい

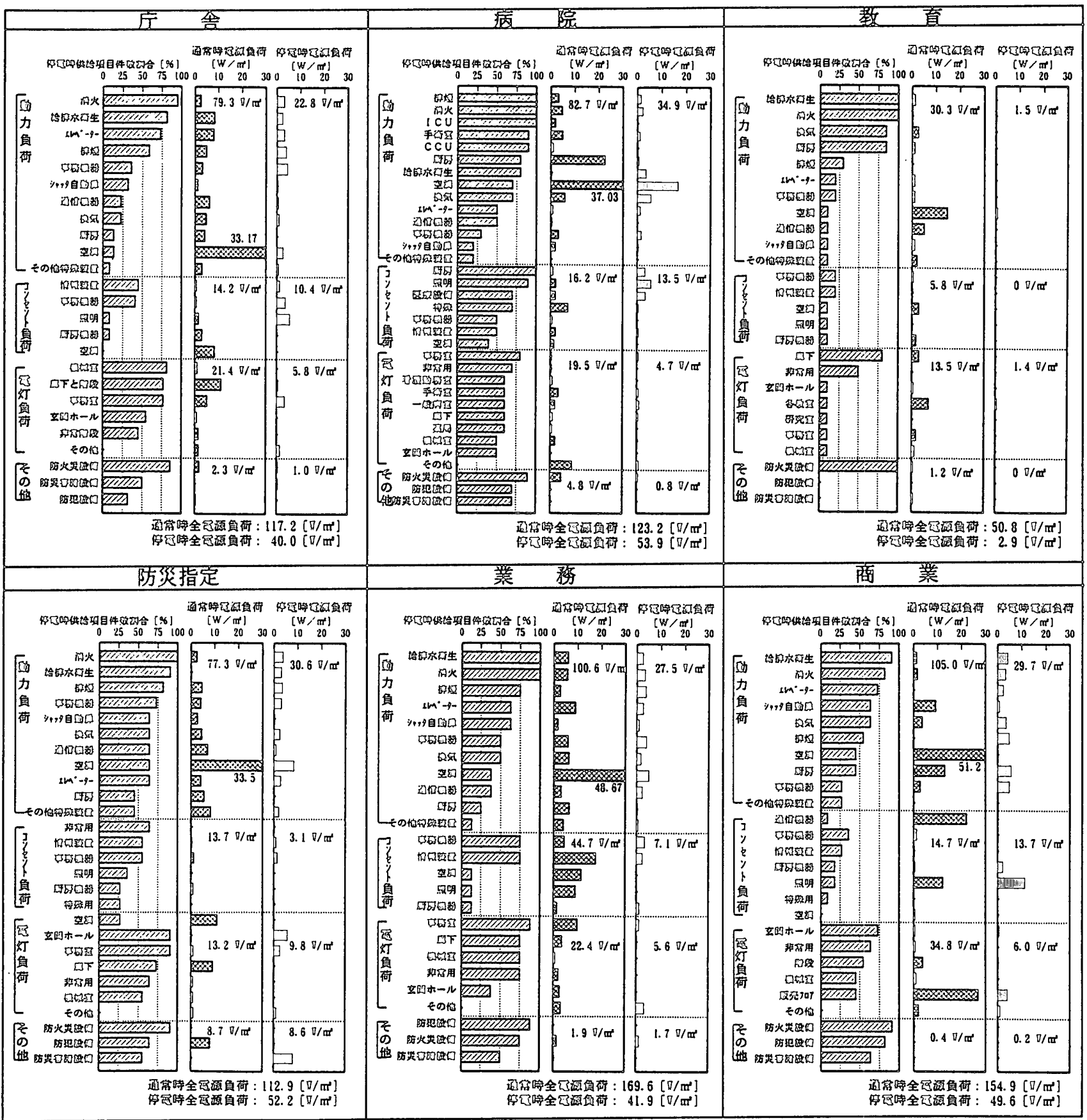

図 8 停電時の非常電源による電力供給項目件数割合と通常時及び停電時の電源負荷容量 


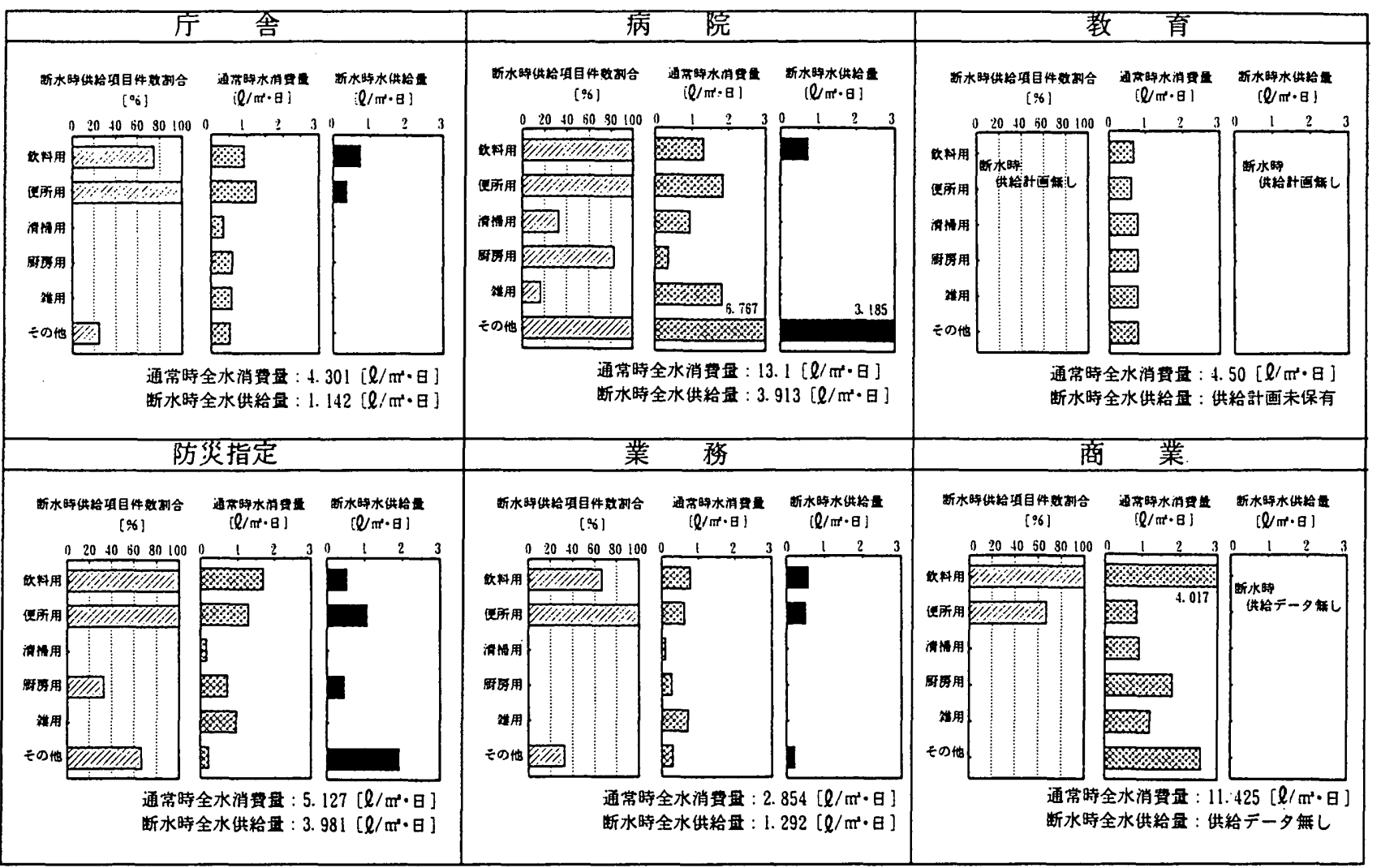

図 9 断水時の備蓄水による給水項目件数割合と 通常時及び停電時の給水容量

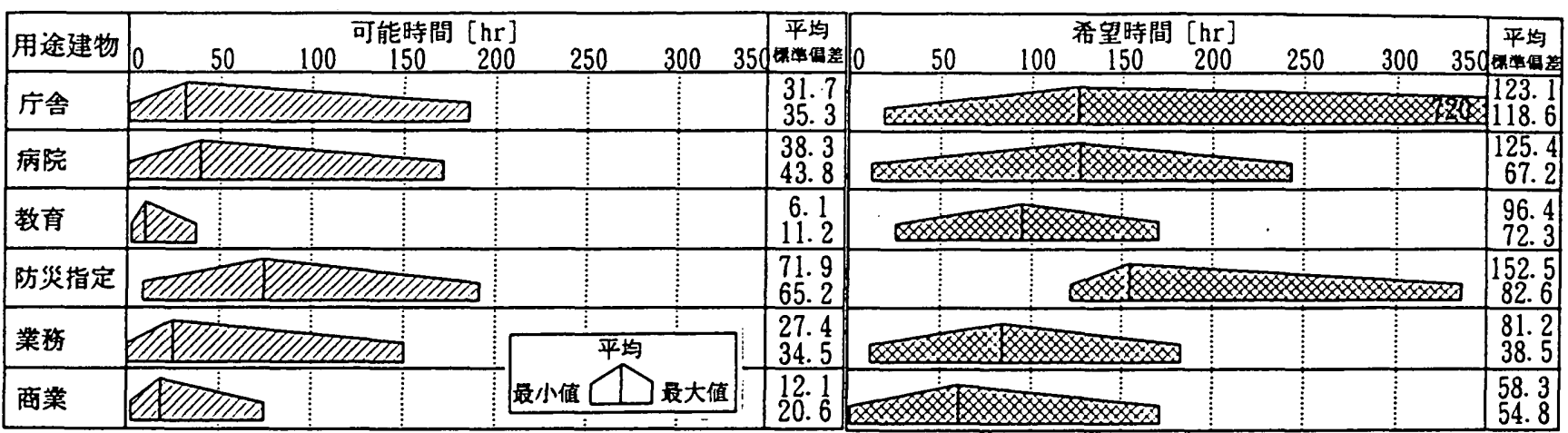

図10 非常時の執務継続可能時間及び希望時間

なかった（図 9)。

\section{5. 非常時の執務継続時間と現状における可能性の検討}

前節で停電時と断水時の電力・水供給項目とその容量を分析した。 本節では、非常時の救援活動及び執務継続時間を分析した上て、電 源機能と給水機能について現状の設備でどの程度の供給が可能かを 検討した。

\section{1 非常時の活動之執務維続時間の分析}

\section{1 ) 非常時の活動亡執務継続可能時間と継続希望時間}

非常時の救援活動及び執務継続可能時間亡継続希望時間を図10に 示す。救援活動及び執務継続可能時間とは、ライフラインの機能が 停止した場合に現在保有している建築設備、備蓄燃料・水で可能な 救嗳活動と執務継続時間である。継続希望時間とは、ライフライン の機能が停止した場合に希望する救援活動及び執務継続時間である。 今後、非常時対策の重要性からここては全建物に対し、執務継続可
能時間と希望時間の最小值や最大值、平均を明らかにした。平均継 続可能時間は、長い順に防災指定が約72時間、病院が約38時間、庁 舎が約32時間、業務が約27時間、商業が約12時間、教育が約6時間で あった。また、平均継続希望時間も前の可能時間が長かった用途建 物が継続希望時間が長かった。平均希望時間の長い順に、防災指定 が約152時間、病院が約125時間、庁舎が約123時間、教育が約96時間、 業務が約81時間、商業が約 58 時間である。特に、教育建物は平均継 続希望時間が可能時間より約16倍も長く要求していた。

2 ) 継続希望時間の充足度

継続希望時間に対する継続可能時間の充足度は、庁舎が約 $25 \%$ 、 病院が約 $30 \%$ 、教育が約6\%、防災指定が約 $47 \%$ 、業務が約33\%、商 業が約 $20 \%$ でった。教育建物を除く防災指定建物の充足度が大き い。

\section{2 電源機能の現状における可能性の検討}

現状の自家発電設備の容量と非常時の想定電力必要量の関係を分 析し、図11に示す。X軸の非常時電力必要量は、各用途建物の通常 
時負荷容量（動力負荷、コンセント負荷、電灯負荷、その他）に対 する停電時供給負荷容量の割合を契約電力に乗じて算定した値て、

Y 軸は、各建物が保有している自家発電機の発電力でる。従って、 $\mathrm{Y}=\mathrm{X}$ の直線より下の部分つまり $\mathrm{Y}<\mathrm{X}$ 範囲は、現状の自家発電 設備容量ては想定電力必要量を供給できないことになる。ここて、 $\mathrm{Y}<\mathrm{X}$ の範囲に分布している件数割合は、宁舎が $36 \%$ 、病院が $54 \%$ 、 教育が0\%、防災指定が27\%、業務が44\%、商業が $22 \%$ でる。なお、 各用途建物の平均非常時電力必要量と平均自家発電力を示すと、仃 舎が317k界と380k界、病院が1, 295kWと984kW、教育が149kWと449kW、 防災指定が1,738kWと2,890kW、業務が1,223kWと1,482kW、商業が796 $\mathrm{kW}$ ¿1, 022kWてある。現保有自家発電設備の容量と備蓄燃料による 非常時の救援活動及び執務継続時間の比較を図12に示す。非常用電 源設備之備蓄燃料による、通常時 $(100 \%)$ と同様に執務を行う場合 の機能稼㗢可能時間は、どの用途建物も約 2 日程度しか稼㗢できな いことになる。

図10での可能時間が図12での非常時に必要最低限の執務を行う場 合の執務可能時間より長いのは、建築設備管理者が非常時の活動レ ベルに応じてその建築設備機能を維持させるという主観的な判断と 簡易算定值とのちがいであると考えられる。

\section{3 洽水機能の現状における可能性の検討}

現状の水槽の容量と断水時の給水量の関係を分析した。ここて、 図 9 をみて分かるように断水時の給水計画を持っていない教育は、 災害時に避難場所となり、商業建物は通常大勢の人が集まるなどの 非常時の建物機能維持が通常時より重要てあると考えられる。よっ て、再度教育と商業建物の給水蛽任者を訪問し、断水時に最小限の 機能維持に必要な水量を通常時の水消費量（飲料水、雑用水、その 他水）に対し、最小限必要とする割合を調查した。その結果、教育

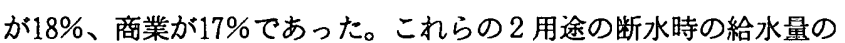
算定は、通常時の一日水消費量に必要割合を乗じて簡易的に算定し た。また、各水槽（受水槽、高置水槽、眝水槽、消防水槽）は満水 状態と仮定した。非常時の給水可能時間を図13に示す。通常時（100 \%) の機能稼㗢可能時間では、通常時と同様、水を100\%使用しても 約 2 日〜 7 日は供給できるという結果を得た。さらに、必要最低限 の機能稼働可能時間では、断水時、防災指定建物以外の建物は必要 最低限の機能維持可能な水を供給すると、非常時の機能稼働継続希 望時間以上供給できることになる。

\section{6. 結論}

（1）東京都地域防災計画の救援・救護 0 を行う防災機関から 4 用 途、一般建物の中で都市中枢機能を持つ建物から 2 用途に関して停 電時の自家発電機機による電力供給計画の有無之、断水時における 備蓄水による給水計画の有無を調査した結果、電力供給計画を持っ てる建物は、防災指定と商業が $92 \%$ 、業務が $76 \%$ 、病院が $69 \%$ 、宁 舎が62\%、教育が $20 \%$ であったが、水配給計画を持つ建物は、全体 的に $30 \%$ 以下の少なさであった。

（2）停電時の自家発電機による電力供給項目件数割合亡断水時の 保有水槽による水供給項目件数割合を明らかにした。その結果、停 電時に $80 \%$ 以上の建物が供給する電源負荷項目を示す之、消火動力、 給排水衛生動力、排煙動力、病院の I C U P C C U 等の手術関係動
力、各事務室や廊下や玄関ホールの電灯、防火災設備、防犯設備用 電源であった。また、断水時に $80 \%$ 以上の建物が供給する水負荷項 目では、飲料用、便所用、その他（主に手術室用と冷却水）であっ たか、教育建物は断水時の供給計画を持っていなかった。

（3）通常時と非常時に供給する電源之水負荷容量を分析した結果、 通常時の各系統別電力負荷ては、圧倒的に動力負荷の空調負荷容量

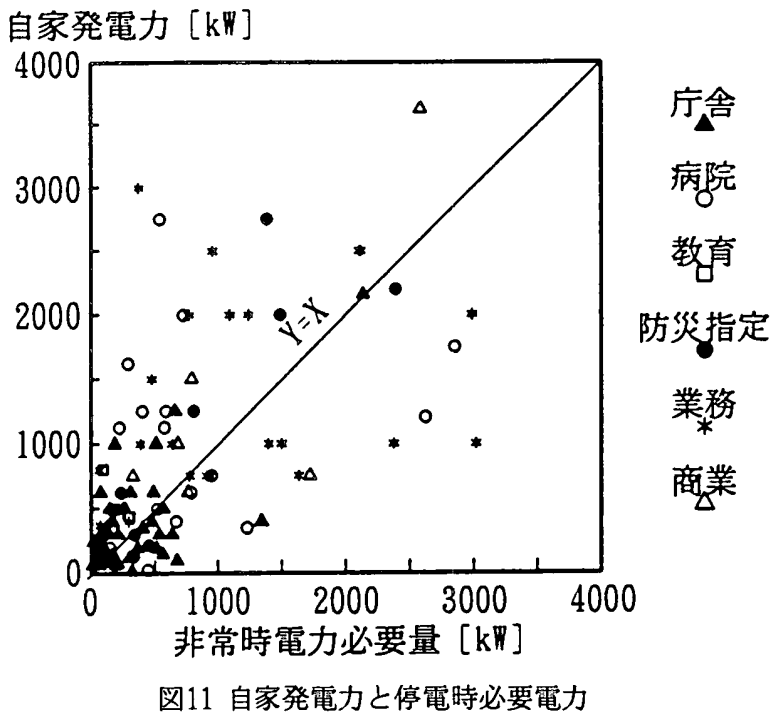

時間 $[\mathrm{hr}]$

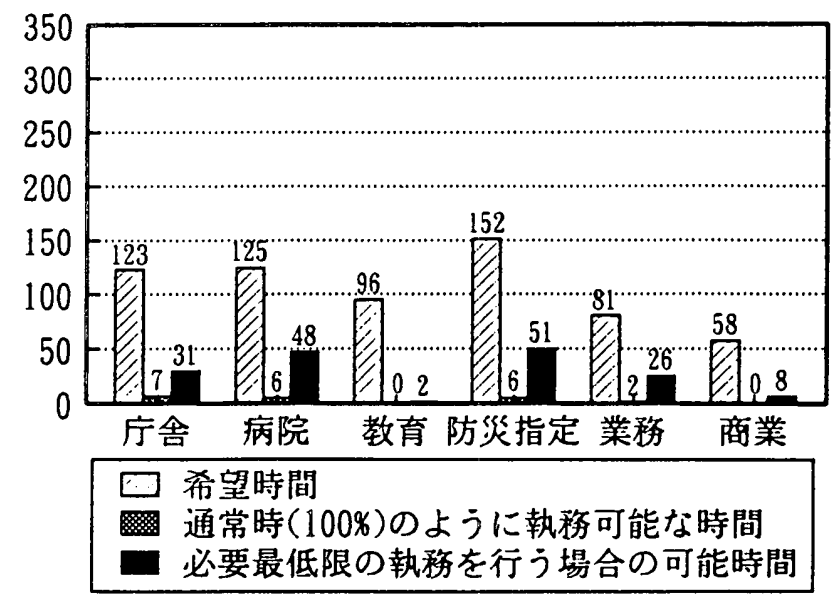

図12 停電時の自家発電機による執務継続時間比較

時間 $[\mathrm{hr}]$

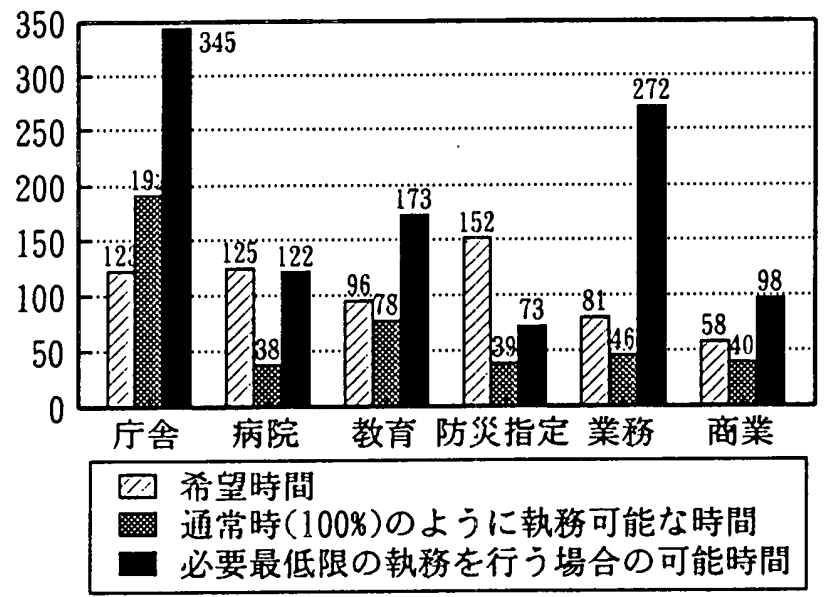

図13 断水時の備蓄水による給水可能時間比較 
が大きいが、停電時になると空調負荷は大きく減らすことに対し、 消火や給排水衛生動力之防火災設備負荷などは停電時にその供給容 量が通常時とほぼ同程度でっった。た、各建物用途別に通常時全 電源負荷容量上停電時全電源負荷容量の比は、庁舎が34\%で、病院

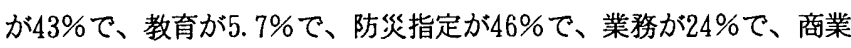
が32\%であった。

各建物用途別に通常時 1 日全水消費量と断水時 1 日全水供給量て は、庁舎が $4.301 \mathrm{l} / \mathrm{m}^{2}$ ・日と $1.142 \mathrm{l} / \mathrm{m}^{2}$ ・日、病院が $13.100 \mathrm{l} / \mathrm{m}^{2}$ ・日 之3. $913 \mathrm{\ell} / \mathrm{m}^{2}$ ・日、教育が $4.500 \mathrm{\ell} / \mathrm{m}^{2}$ ・日と断水時供給計画無し、防 災指定が5. $127 \mathrm{\ell} / \mathrm{m}^{2}$ ・日と $3.981 \mathrm{\ell} / \mathrm{m}^{2}$ ・日、業務が $2.854 \mathrm{\ell} / \mathrm{m}^{2}$ ・日と1. $292 \mathrm{\ell} / \mathrm{m}^{2}$ ・日、商業が $11.425 \mathrm{\ell} / \mathrm{m}^{2} ・$ 日と断水時供給水量のデー夕無し であった。

（4）非常時に各建物の保有建築設備之燃料備蓄による救援活動及 び執務継続可能時間と希望時間を検討した。その結果、継続希望時 間に対する継続可能時間の充足度は、宁舎が約 $25 \%$ 、病院が約30\%、 教育が約 $6 \%$ 、防災指定が約 $47 \%$ 、業務が約 $33 \%$ 、商業が約 $20 \%$ であ った。教育建物の充足度が他の建物より低かった。

（5）電源機能については、庁舎が $36 \%$ 、病院が $54 \%$ 、教育が $0 \%$ 、 防災指定が $27 \%$ 、業務が $44 \%$ 、商業が $22 \%$ の建物で現状の自家発電 設備容量ては想定電力必要量を供給できない。また、非常用電源設 備と備蓄燃料による、通常時（100\%）の機能稼働可能時間では、厅 舎が 31 時間、病院が 48 時間、教育が 2 時間、防災指定が51時間、業務 が26時間、商業が8時間で、どの用途建物も48時間以上は機能維持不 可能であることを明らかにした。

（6）給水機能については、現状の水槽の容量による非常時の想定 一日水需要量の給水可能時間は、通常時 $(100 \%)$ の機能稼働可能時 間では、庁舎が192時間、病院が38間、教育が78時間、防災指定が39 時間、業務が 46 時間、商業が 40 時間で、通常時と同様、水を $100 \%$ 使 用しても約 2 日〜 7 日は供給できることと、必要最低限の機能維持 可能時間では、庁舎が345時間、病院が122時間、教育が173時間、防 災指定が73時間、業務が272時間、商業が98時間で、断水時、防災指 定建物以外の建物は必要最低限の機能維持に必要な水を供給すると、 非常時の機能維持継続希望時間以上供給できることを明らかにした。

\section{謝 辞}

本研究を進めるに当たり、貴重なデー夕を提供していただきまし た各用途建物の設備担当関係者に多大なるご協力を得た。また、調 查においては当時研究室の修士学生であった佐々木淳一君にご協力 を得た。ここに記し、深く感謝の意を表します。

\section{注）}

1）本論文における調查は、大震災等の広域災害時に上下水道、電気、ガス等のラ イフライン機能が停止した掦合を想定している。したがって、回答者の認識を明 確にするために、調查には「通常時」と「非常時」の言葉を以下のように定義し て使用した。即ち、「通常時」之は、通常の状態て建築物か機能し、上下水道、 電気、ガス等のライフラインの機能が持続的に維持されている状態を示し、「非 常時」亡は、広城炎害時等で建筑物汃必要最低限の機能を継続したいか、上下 水道、電気、ガス等のライフライインの供給機能が停止した状態である、と定義 した。
付表 1 建築基準法による予備電力

\begin{tabular}{|c|c|c|c|c|c|c|}
\hline \multicolumn{2}{|c|}{ 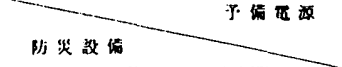 } & 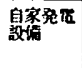 & 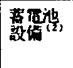 & 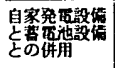 & 容焉) & 根夠集文 \\
\hline \multirow{4}{*}{ 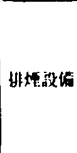 } & 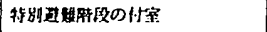 & \multirow{4}{*}{0} & \multirow{4}{*}{0} & \multirow{4}{*}{-} & 30 分間 & \multirow{4}{*}{ 命条126条の3 } \\
\hline & 特残建物なと & & & & 30 分圈 & \\
\hline & 地下们の条俏えの接する地下㨁 & & & & 30 分城 & \\
\hline & 非落川エレペーターの乘降ロビー & & & & 30 分間 & \\
\hline \multirow{4}{*}{ 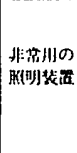 } & 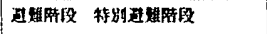 & \multirow{4}{*}{$O^{(1)}$} & \multirow{4}{*}{0} & \multirow{4}{*}{$O^{(3)}$} & 30 分間 & \multirow{4}{*}{ 令策126条の5 } \\
\hline & 特捈建物など & & & & 30 分间 & \\
\hline & 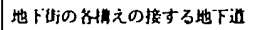 & & & & 30 分用 & \\
\hline & 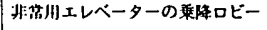 & & & & 30 分囬 & \\
\hline \multicolumn{2}{|c|}{ 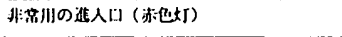 } & 0 & 0 & - & 30 分阔 & 告示1831 \\
\hline 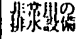 & 地下们の条梢えの接する地下计 & O & O & - & 30 分間 & 告示1730 \\
\hline \multicolumn{2}{|c|}{ 非茣川エレペーター } & 0 & - & - & 60 分間 & 令年129条の13の3 \\
\hline \multicolumn{2}{|c|}{$\beta_{j}$ 火 $\overline{i j}$} & 0 & 0 & - & 30 分罡 & 告示2563 \\
\hline \multicolumn{2}{|c|}{ タ } & 0 & 0 & - & 30 分圆 & 告示1097 \\
\hline
\end{tabular}

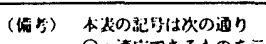

0 : 通灾てきるものを宗す

通いてきないもの、またははとんと用いられないものを示す

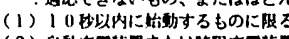

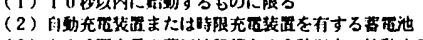

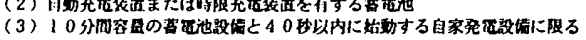

付表 2 消防法による非常電源

\begin{tabular}{|c|c|c|c|c|c|c|}
\hline 防炎設借 & 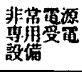 & 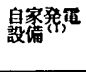 & 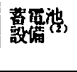 & 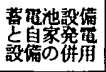 & 容昌) & 根拋条文 \\
\hline 尾内消火拴設偖 & $\Delta$ & 0 & 0 & - & 30 分間 & 則12条4号 \\
\hline スプリンクラー設偏 & $\triangle$ & 0 & 0 & - & 30 分周 & 則14条1項6の2号 \\
\hline 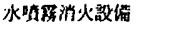 & $\Delta$ & 0 & 0 & - & 30 分間 & 則16条3項2号 \\
\hline 泡消火钤備 & $\Delta$ & O & 0 & - & 30 分閵 & 則18条4項13号 \\
\hline 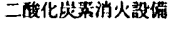 & - & 0 & 0 & - & 60 分間 & 則19条4項20号 \\
\hline ハロゲン化物消火発備 & - & $\mathrm{O}$ & O & - & 60 分間 & 則20条4項15号 \\
\hline 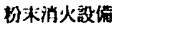 & - & 0 & $\mathrm{O}$ & - & 60 分湖 & 則21条4項17号 \\
\hline 目動火災银知設诺 & $\Delta$ & - & 0 & - & 10 分間 & 則24笨4号 \\
\hline 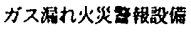 & - & - & 0 & $O^{(3)}$ & 10 分間 & 則24条203 1項7号 \\
\hline 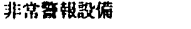 & $\Delta$ & - & 0 & - & 10 分間 & 則25条2 2項5号 \\
\hline 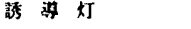 & - & - & $\mathrm{O}$ & - & 20 分間 & 則28条3 1項7号 \\
\hline 排娷 呚 侮 & $\Delta$ & 0 & 0 & - & 30 分間 & 則30炛2号 \\
\hline 非莟コンセント請储 & $\Delta$ & 0 & 0 & - & 30 分用 & 則31条2 8号 \\
\hline 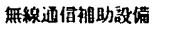 & $\Delta$ & - & 0 & - & 30 分間 & 則31集2の2 7号 \\
\hline
\end{tabular}

（傮考）（1）本表の記号は次の通り

○: 通応するすのを示す

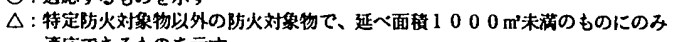
嗃応てきるものを示す

一 : 適危できないものを示す

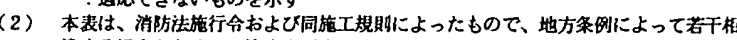
遇する堨合がるので注望を要する

(1) 自動的に切替えられるものてあること

（2）自動的に切替え、自動的に復西てきるものてあること

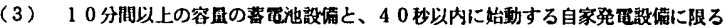

2) 建築設備における法規

近年に至り、非常時に人命の安全と財産の損害を最小限に抑えるため、建築基 準法、消防法、その他の法令・条例が改正された結果、発電設備は非常電源の一 部としてその設置が法的に義枒化されるに至り、適用の箅囲も拡大されているの が現状である。よって、各建築物は、非常時に備えて、ある程度建物機能を維持 するため、建築シスデムとして、自家用発電機や詝油槽などを所有している。非 常時に関する防災電源については、主に(1)建築基準法（1950年, 法律第49号）(2) 消防法（1948年，法律 第186号) (3)工業標準化法 (1949年, 法律 第185号) に よる日本工業規格（JIS）において、以下のようにその設置義務に関して規定 されている。

(1)建築基準法 （文献8，9，10） 建築基準法で、避難誘導設備の稼倬確保を目的に、「予備電倾」として付表 1ように防災電源の設置か矮務つけられている。法令における予備電源には、 「自家発電設備」「畄電池設備」の二種類があり、それぞれについて使用可能, 不可能な防災設備がある。この揚合、それぞれの法令に適用するものを別々に施 
付表 3 JIS-T1022による病院電気設備の安全基淮

\begin{tabular}{|c|c|c|c|c|c|c|c|}
\hline \multirow{2}{*}{ 医用室 (1) } & \multicolumn{2}{|c|}{ 医用接地方法 } & \multirow{2}{*}{$\begin{array}{l}\text { 韭接地 } \\
\text { 熟第 }\end{array}$} & \multicolumn{3}{|c|}{ 非常電源 ${ }^{(2)}$} & \multirow{2}{*}{$\begin{array}{l}\text { 容豆 } \\
\text { (時間) }\end{array}$} \\
\hline & 保掏地 & 等電位 & & 一般 & 特别 & 特時 & \\
\hline 䀛部手術室 & 0 & 0 & 0 & 0 & $\Delta$ & 0 & \\
\hline 胸部手術室以外の手術室 & $\mathrm{O}$ & $\triangle$ & 0 & 0 & $\triangle$ & 0 & \\
\hline リカパリー室（回传室） & $\mathrm{O}$ & $\Delta$ & $\Delta$ & 0 & $\Delta$ & - & \\
\hline I C U（倡中治宛室） & 0 & 0 & $\Delta$ & 0 & $\triangle$ & - & \\
\hline 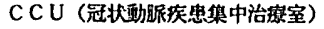 & 0 & 0 & $\Delta$ & $\mathrm{O}$ & $\triangle$ & - & \\
\hline 重教病空 & 0 & $\triangle$ & $\triangle$ & 0 & $\triangle$ & - & \\
\hline 心カテーテル検查室 & 0 & 0 & 0 & 0 & $x$ & $\triangle$ & \\
\hline 心血管 X瀪造距室 & $\mathrm{O}$ & 0 & 0 & $\mathrm{O}$ & $\triangle$ & $\Delta$ & 10 \\
\hline 分凂室 & 0 & $\triangle$ & $\triangle$ & 0 & $x$ & $\triangle$ & \\
\hline 生理湌查室 & 0 & $\triangle$ & $x$ & $\triangle$ & $x$ & - & \\
\hline 内視籍室 & $\mathrm{O}$ & $\triangle$ & $x$ & $\triangle$ & $x$ & - & \\
\hline X線揄植空 & 0 & $\times$ & $x$ & $\Delta$ & $x$ & - & \\
\hline 陣缩室 & 0 & $x$ & $x$ & $\triangle$ & $x$ & - & \\
\hline 一般病室 & 0 & $x$ & $x$ & $\Delta$ & $x$ & - & \\
\hline 訩察室 & $\mathrm{O}$ & - & - & $\triangle$ & - & - & \\
\hline 険体揄查室 & 0 & - & - & $\triangle$ & - & - & \\
\hline
\end{tabular}

記号の总味 ○設けなければならない、設けることが望ましい

$$
\text { ×設けなくてよい - 㷋当しない }
$$

(1) この表の室名は、删示である

(2) 非常西源は、医用空以外の西気設備にも適用される

付表 4 消防法による消防用水の技街基染

\begin{tabular}{|c|c|c|c|}
\hline \multicolumn{2}{|c|}{ 面目 } & 基 & 閶保法命 \\
\hline \multirow[t]{4}{*}{$\begin{array}{l}\text { 消 } \\
\text { 防 } \\
\text { 用 }\end{array}$} & \multirow[t]{2}{*}{ 水些 } & 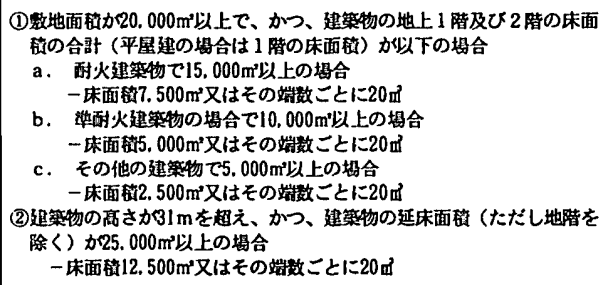 & Aे27-3-1 \\
\hline & & 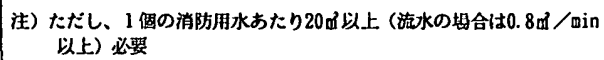 & ลे27-3-2 \\
\hline & 水平距醀 & $100 \mathrm{~m}$ 以下 & 命27-3-2 \\
\hline & 陪沼坦所 & 消防ポンプ自動車が $2 \mathrm{~m}$ 以内に接近することがてささるように即けること & Aि27-3-4 \\
\hline
\end{tabular}

設する必要はなく、各設借の機能に支障を生じなければ、共用しても支障ないこ とになっている。

(2)消防法 (文献8.9.10)

消防法ては、避難, 警報, 消火設備の稼働確保を目的に「非常電源」として付表 2 のように防災奄源の設置が義務つけりれている。法令における防災電源には、

「非常電源表用受電設備」「自家発電設備」「蓄電池設㣁」の三種類があり、そ れぞれについて使用可能，不可能な防災陪備がある。この揭合、それぞれの法令 に適用するものを別々に施設する必要はなく、各設備の機能に支障を生しなけれ は、共用しても支障ないことになっている。

(3)病院龟源設備の安全基準（JIS-T1022）（文献12）

各種建物用途のうち、特に病院に関しては、工業標準化法 (昭和 24 年, 法律第 185 号) による日本工業規格（JＩＳ）て、T 1022 「病院電気設備の安 全基洮」として非常電源について表 $1-5$ のように規定されており、国際電気標 準会讙（ＩＥＣ）でもその規格化について検討が進められている。

(4) 電気孪業法 (文献9）

以上に挙げた防災電源は、(4)電気事業法（昭和 39 年, 法律 第 170 号) で一 般的に「自家用電気設備」として取り扱われ、その規制を受ける。また、これに 関連し、その関係法令によっても規定を受け、例えば(5)電気設備に関する技術基 莑を定める省令（昭和 40 年, 通商産業省令法律第 61 号) において、常用電源 と電気的に接続させないなど、施設方法などが規定されている。

3）消防用水は消防法に基つきき設置加義務つけられている。消防用水は河川、湖 · 沼、海、プール、消火水槽など常時消火水として利用できるものでけけれはなら ない。付表 4 に消防法の定める消防用水に関する基学を示す。

4) 東京都地域防災計画（文献 1)では、災害時における领料水の確保については、 生命維持に必要な樶低必要量として、1 日1 人 3 リットルの給水を基菹としてい
ろ。

5 ）計算上、非常時想定必要電力負荷が自家発電設㣁の容量よりその值か大きい建 物は、現保有自家発電設備を $100 \%$ 稼働した時、得られる電力を非常時想定必要 電力負荷とした。

\section{参考文献}

1) 東京都防災会議：果京都地域防災計画震災編，1992

2) 東京都 : 第五次東京都震災予防計面, 1993.8

3) 神奈川県, 千葉県, 埼玉県防災会議 : 神奈川県, 千葉県, 埼玉県地域防火計画 震災螎, 1992

4）掼浜市防火会議：横浜市地域防災計画地震対策螎，1989

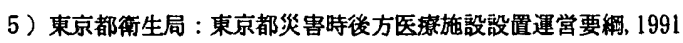

6) 尾島俊雄：建築設備の技術革新, 早稲田大学理工総研シリーズ 6, 1995.11

7）尾島俊雄 : 建築の光熱水貫, 早稲田大学理工淞研シリーズ $3 ， 1995.6$

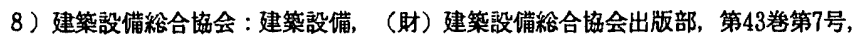
1992. 7

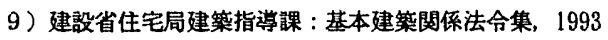

10）建桎大臣官房官庁営橏部監修：建築設備設計要領， 1990.2

11）工藤金三郎 : 自家発電設備の機能の維持, 病院設備，PP. $23 \sim 30 ， 1977.9$

12）日本工業標準調查会審議：病院電気設備の安全基準，J I S - T 1022, 日本 規格努会, 1982.11

13）日野宗門：大規模災害に対する地域の防災管理システムに関する研究，1987.6

14）久田俗彦：地震と建築，鹿島出版会，1978.5

15）建築㗄料研究社：建築設計资料，52号地域防災施設，1994.6

16）（財）日本建築防炎協会：建築防㷋' $95.1 \sim 10,1995.1 \sim 10$

17）南 雅彦, 佐土原聁, 村上處直: 病院建築における非常時エネルギー需要の分 析一都市におけるエネルギーライフラインに関する基碳的研究その 1 -, 日本建 筑学会大会学術潇演梗概集, PP. 1275 1276, 1991.9

18）内藤祯俊, 佐土原聁, 村上處直 : 事枒所建築の非常時エネルギー需要の分析一 都市におけるエネルギーライフラインに関する基群的研究 その 2 -, 日本建築 学会大会学術講演梗概集, PP. 1277 1278, 1991.9

19）洪元和, 村上公哉, 尾島俊雄: 病院の非常時建築設㣁機能の重要度及び必要 割合の調查分析, 日本建筑学会計画系論文集第458号, PP. 17 25, 1994.4

20）洪 元和, 村上公哉, 尾島绤雄 : 庁舎の非常時建築設備機能の重要度及び必要 割合の調查分析，日本建築学会計画系論文集 第468号，PP. 37 45, 1995.2

21）佐々木淳一, 洪 元和, 尾島俊雄他: 東京における都市機能維持のためのライ

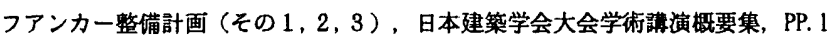
$001 \sim 1006, \quad 1995.9$

22）洪 元和, 高橋信之, 尾島俊雄 : 停電時におりる各種建物の自家発奄による電 力供給計画に関する研究，日本建築学会大会学街講演梗概集，1996. 9

（1996年 6 月 3 日原稿受理，1996年10月31日採用決定） 